\title{
Reproductive behavior of intertidal hermit crabs (Decapoda, Anomura) in southeastern Brazil
}

\author{
Alexander Turra \\ Laboratório de Biologia Aquática, Curso de Ciências Biológicas, Campus II, Centro Universitário da Fundação de Ensino \\ Octávio Bastos. 13870-159 São João da Boa Vista, São Paulo, Brasil. E-mail: turra@feob.br
}

\begin{abstract}
The reproductive behavior of four intertidal hermit crab species [Clibanarius antillensis Stimpson, 1859, C. sclopetarius (Herbst, 1796), C. vittatus (Bosc, 1802), and Pagurus criniticornis (Dana, 1852)] was studied in São Sebastião Channel, southeastern Brazil. The overall behavior followed previous descriptions for Diogenid and Pagurid hermit crabs but some particular differences were recorded. Male to male agonistic encounters over females and guarding behavior were more common to C. sclopetarius, C. vittatus, and Pagurus criniticornis. During guarding, males clearly grasped females' chelipeds, eyestalks, and the margins of their shell apertures. This oblique guarding and, simultaneously, accessing behavior (OGAP) has never been described for hermit crabs and was more common to $C$. sclopetarius and C. vittatus. Pagurus criniticornis did not present the typical jerking behavior of pagurids. Multiple copulations between a single pair were recorded in all species while in only one occasion a female of $C$. vittatus was observed copulating with two males. In the post-copulatory behavior males held females for some time and, after that, they were left inactive and sometimes totally to partially buried in the substrate. In mating pairs of all species males were larger than females and two individuals (out of 23) of $C$. antillensis, one (out of 5) of $C$. sclopetarius and one (out of 3) of C. vittatus, which courted successfully as males fertilizing females' eggs, were demonstrated to be intersex, with both male and female gonopores.

KEY WORDS. Clibanarius, Pagurus, courtship, intersex.
\end{abstract}

RESUMO. Comportamento reprodutivo de ermitões (Decapoda, Anomura) entremarés no sudeste brasileiro. O comportamento reprodutivo de quatro espécies de caranguejos ermitões entremarés [Clibanarius antillensis Stimpson, 1859, C. sclopetarius (Herbst, 1796), C. vittatus (Bosc, 1802) e Pagurus criniticornis (Dana, 1852)] foi estudado no Canal de São Sebastião, sudeste brasileiro. O comportamento geral destas espécies seguiu descrições prévias para ermitões das famílias Diogenidae e Paguridae mas algumas diferenças foram registradas. Encontros agonísticos entre machos para disputar fêmeas e o comportamento de guarda foram mais comuns a $C$. sclopetarius, $C$. vittatus e Pagurus criniticornis. Durante a guarda os machos claramente tocavam os quelípodos, pedúnculos oculares e as margens da abertura das conchas das fêmeas. Este comportamento de guardar e, simultaneamente, estimular as fêmeas em uma posição oblíqua (OGAP) nunca havia sido registrado e, no presente estudo, foi mais conspícuo em C. sclopetarius e C. vittatus. Pagurus criniticornis não apresentou o comportamento típico da família Paguridae denominado "jerking" (machos sacudindo as fêmeas). Cópulas múltiplas em um mesmo par foram registradas para todas as espécies enquanto apenas em uma ocasião uma fêmea de $C$. vittatus foi copulada por dois machos diferentes. Após a cópula os machos continuavam segurando as fêmeas por algum tempo até que elas eram deixadas inativas e, em algumas vezes, totalmente ou parcialmente enterradas no substrato. Os machos foram maiores que as fêmeas nos pares que acasalaram em todas as espécies estudadas e dois indivíduos (de um total de 23) de $C$. antillensis, um (de 5) de C. sclopetarius e um (de 3) de $C$. vittatus, que acasalaram com sucesso fertilizando os ovos das fêmeas, foram identificados como intersexo, com gonóporos tanto maculinos quanto femininos.

PALAVRAS CHAVE. Clibanarius, Pagurus, acasalamento, intersexo.

Hermit crabs have a very complex behavioral repertoire related or not with their characteristic dependence on gastropod shells. They have elaborated shell investigation behaviors to access shell quality (see Elwood \& NeIL 1992 for a review) and employ particular agonistic displays in shell and reproductive contests
(HAZLETT 1966). Finally, hermit crabs present pre-copulatory and mating behaviors with which males locate and mate females.

HAZLETT (1966) did pioneer observations on the behavior of hermit crabs and revealed that agonistic and reproductive displays were family-related characteristics although reproduc-

Revista Brasileira de Zoologia 22 (2): 313-319, junho 2005 
tive behaviors presented higher variability among species of the same family. In general, the most common behavior of Diogenid hermit crabs is rotating/rocking the female, while male jerking the female toward him is frequent in pagurids (HazLETT 1966). More information on the reproductive behavior became available over the years (HAzLETT 1968, 1972, 1975, 1986, 1989, 1996a, 1996b, de Wilde 1973, Helfman 1977, Asakura 1987, Hazlett \& Baron 1989, Harvey 1990, Goshima et al. 1998), elucidating many questions related to the complex life-style of hermit crabs. Questions such as, how long does fecundation last, how many times do a single pair copulate, and how many males can copulate with a single female were addressed in these studies.

Behavioral studies on Brazilian hermit crabs are recent (Turra \& Leite 2000a, Turra \& Denadai 2002, 2003). The little information on the reproductive behavior of species that occur along the Brazilian coast was described in the studies of HAzLETT $(1966,1972,1996 a, b)$ on populations located in the Caribbean and southern USA. In these studies, Hazlett observed only one successful mating of C. antillensis Stimpson, 1859 and partially described the sexual behavior of C. sclopetarius (Herbst, 1796) (synonym of C. cubensis; Forest \& SaInt LaUrent 1968). The reproductive behavior of $C$. vittatus (Bosc, 1802) was described in detail only recently (HAzLETT 1996b) while that of Pagurus criniticornis (Dana, 1852) has never been observed. The present study describes in detail the pre and post-copulatory behaviors of populations of these four species in southeastern Brazil and compares them with previous descriptions.

\section{MATERIAL AND METHODS}

The studied species are Atlantic intertidal and shallow subtidal hermit crabs (Forest \& SAINT LAURENT 1968) that coexist in the intertidal region of Pernambuco Islet and of an adjacent mud flat $\left(23^{\circ} 49^{\prime} \mathrm{S}, 45^{\circ} 24^{\prime} \mathrm{W}\right)$ in the mainland part of the São Sebastião Channel, northern coast of São Paulo State, southeastern Brazil (TuRRA et al. 2000). A large number of individuals (> 200) of each species were collected in this area and maintained in the laboratory in plastic pools with running seawater. The bottom of the pools was filled with sediment from the collection site and the crabs were fed daily with fresh fish or mussel meat.

A total of $50 \mathrm{~h}$ of observations on the reproductive behavior were carried out from March to April 2001 under a natural photoperiod and similarly distributed among species and periods of the day (morning, afternoon and night). Despite the studied hermit crab species are more active at afternoon and night (except Pagurus criniticornis, TurRa and DENADAI 2003), reproductive behaviors were frequently verified at morning observations and no evident differences were recorded among periods. The pools were observed carefully in these periods until a courting pair was identified. Attention was then paid only to the pair and all movements and displays, as well as the time they lasted, were recorded. The behavioral patterns of the crabs were observed and described according to HAzLETT (1966, 1972,
$1996 \mathrm{a}, \mathrm{b})$. For schemes of the most representative behaviors see HazletT (op. cit.). Observations ceased when the pair separated without copulating. Nocturnal observations were carried out using red lights to prevent alterations in crab behavior (HAzletT op. cit.). After copulation, males and females were removed from their shells and measured (shield length, $\mathrm{mm}$ ) to establish a ratio between their sizes. Observations on both successful and unsuccessful courtships were used to describe the reproductive behavior of the studied species. A total of 23 complete successful courtships were recorded for C. antillensis, 5 for C. sclopetarius, 3 for C. vittatus and 7 for P. criniticornis.

\section{RESULTS AND DISCUSSION}

\section{Clibanarius antillensis Stimpson, 1859}

There were two possible initial outcomes when a male of C. antillensis accessed a female: (1) the female withdrew into her shell and remained inactive or (2) the female tried to escape. Courtship could proceed in both situations due to male displays. When the female tried to escape, the male held her shell and, sometimes, exhibited a guarding/accessing behavior (This behavior was more commonly shown by C. sclopetarius and $C$. vittatus than by $C$. antillensis and is described in detail below). I observed one pair of $C$. antillensis in this guarding position until the female molted. Some females escaped when males released them briefly during male-male agonistic encounters. However, fights among males for females were less common in C. antillensis than in C. sclopetarius and C. vittatus. When a male was succeeded in courtship (or after a female have molted), he manipulated/rotated her shell until their shell openings were positioned in front of each other, i.e., in the opposed position (Hazletr 1966). Then the male held the female's shell with his ambulatory legs (second and third pairs of pereopods), while his chelipeds were introduced in the opening of her shell. Some females had molted recently as evidenced by the exuvia or by their soft exoskeletons, while other courted females presented hardened exoskeletons and no exuvia. This suggests that copulation is not dependent upon the female molt in this species.

Males were always larger than females in the observed mates (mean size ratio: $37 \%$, range: 1 to $100 \%$ ). In two successful courtships the "males" have had gonopores developed on the coxae of both the third and fifth pereopods, thus evidencing an intersex condition (TurRa \& LeITE 2000b). Relatively largesized males (in relation to females) lifted females off the substrate and/or held their shells almost completely inside the opening of their relatively larger shell. They remained in that position from hours to more than a full day.

After that, males executed behavioral displays to stimulate females. They did frequent up and down cheliped tapping movements to grasp/pick females' chelipeds or the internal lip of their shell. One or both chelipeds were used in such displays, which were characterized by the chelae held at a right angle 
with carpus. The first ambulatory legs of males also grasped females' chelipeds or shells in this pre-copulatory behavior. Cheliped tapping was alternated with closure of females' shell aperture by males' chelipeds (one or both). Also alternating with cheliped grasping and tapping, males $C$. antillensis presented gentle and violent rocking movements as previously described for this species and for C. tricolor by HAzLETT (1966). Gentle rocking was alternated with cheliped tapping while violent rocking was recorded as a response of males to a quick retraction of females into their shells. During violent rocking males tapped both internal and external lips of females' shell apertures. The duration and intensity of violent rocking enhanced as copulation approached. In some cases, these behaviors were also alternated with rotation of females' shells by males.

Cheliped and antennular movements by the females in the region of the males' eyestalk and antennules provided the signal to them that they were ready for copulation. Then, males and females eased out of their shells and copulated for a few seconds ( 2 to 3 seconds). During copulation, the males' and females' ambulatory legs were intertwined; their gonoperes (coxae of fifth pereopods of the males, coxae of the third pereopods of the females) in contact for the transfer of spermatophores. Two or more subsequent copulations and up to 17 copulatory attempts were reported in one pair. In each trial/attempt the female eased out of and retracted abruptly into her shell. Male violent rocking followed each female retraction.

Little post-copulatory behavior was observed in $C$. antillensis. After copulation, males grasped the lips of the apertures of females' shells up to 2 to 3 hours. Then, males pushed females away and exhibited some aggressive behavior (in general cheliped extensions) toward them. After that, males frequently walked away while females remained inactive.

Females which were removed from their shells right after they had been released by the males had eggs attached to the pleopods and hardened exoskeletons. This demonstrates that males guarded females until they have extruded the eggs (see also HAzLetT 1966). One female recently released by a male was removed from her shell and immediately began to actively remove the eggs from the pleopods with her chela.

HAZLETT (1966) observed only one complete courtship of C. antillensis and suggested it was very similar to that described for C. tricolor. The detailed observations of the reproductive behavior of $C$. antillensis in the present study confirm that it occurs exactly as described for C. tricolor (HAzLetT 1966). A male copulated more than once in $C$. antillensis while copulation of a female with more than one male, which had been recorded for C. tricolor (HAZLETT 1966), was not reported in this species.

\section{Clibanarius sclopetarius (Herbst, 1796)}

Males of $C$. sclopetarius located sexually interested females in several different ways. Males located females during occasional encounters while others were able to track them at distance. Males were also capable of locating partially buried fe-

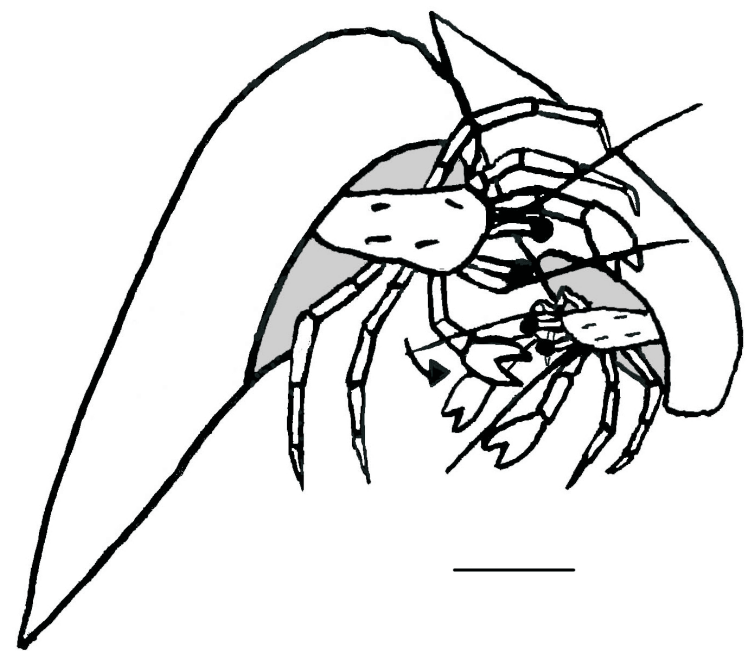

Figure 1. Diagrammatic sketch of the opposite guarding accessing position (OGAP) presented during both pre and postcopulatory behavior by $C$. sclopetarius, $C$. vittatus and $P$. criniticornis. Note that male (larger individual) grasp/pick female (smaller individual) with his chelipeds while holding the female's shell. Scale line: $5 \mathrm{~mm}$.

males while others were attracted to courting pairs. When males located females they could (if they were able to retain the females) court them using one of two, sometime alternating, patterns. The first includes turning the females' shells into the opposed and using up and down cheliped tapping movements, similar to those of $C$. antillensis, or grasp/pick movements at the apertures of females' shells. The second pattern consisted of grasp/pick movements toward the females during guarding displays. Males frequently turned the females' shells down with the apertures facing the substrate and partially covered their shells with their two left ambulatories (Fig. 1). The pairs then maintained their shells in an oblique position with almost a right angle between shell aperture planes. The males placed their left chelipeds on the external lips of the aperture of females' shells. Males right chelipeds (and less frequently first and second right ambulatory legs) were used to grasp/pick the external lips of the females' shell apertures, chelipeds, and eyestalks. Males did more intense grasp/pick movements as a response to females that tried to escape. Then, females extended their chelipeds and grasped males' chelipeds. The relative position of the mating pair was very similar to the guarding behavior described for C. vittatus by HazLeTt (1996b), but males were not reported grasping females in this previous study. This more complex behavior, i.e., grasping in oblique position, was named oblique guarding/accessing position (OGAP, see figure 1 for a diagrammatic sketch). When competing males approached the courting pairs, the defending males immediately took up an OGAP and also displayed agonistic behaviors toward attacking males.

Revista Brasileira de Zoologia 22 (2): 313-319, junho 2005 
The way grasping occurred during OGAP seemed to be related to the shell species used by males. When using elongated medium spire shells, such as those of Stramonita haemastoma (Linnaeus, 1767), Chicoreus senegalensis (Gmelin, 1790), and Cymatium partenopeum (von Salis, 1793), males remained in an erect position in relation to the substrate with their ventral part parallel to the bottom. In contrast, when living in globose low spire shells, such as those of Astraea phoebia (Röding, 1798), the males were laying their left side on the sediment. These crabs could not hold up themselves with their left ambulatories when in OGAP. The shell external lips held up the males, which were able to used their free left ambulatory legs to grasp/pick females. It was not evaluated in the present study if individuals of $C$. sclopetarius in elongated shells were in advantage in relation to those in globose ones, but the effect of inadequate shell types or sizes on the reproductive success of males was clearly demonstrated (HAZLETT \& BARON 1989, HazLeTt 1989, 1996a, b).

Male-male agonistic behaviors to defend females were very similar to those described for other Diogenid hermit crabs by Hazlett (1966). Competing/attacking males generally approached the courting pairs abruptly. The defending males tried to push them away by ambulatory raises and cheliped extensions. Attacking males were generally caused to roll. In more extreme fights the defending males displayed ambulatory pokes toward the eyestalks of the attacking males. Cheliped presentation was not recorded in such fights.

The accessing behavior of males, opposed position and OGAP, lasted from a few hours to more than $24 \mathrm{~h}$ prior to copulation. They were alternated with each other and with rotation of females' shells as described for C. vittatus by HAzLETT (1996b). After that, the pairs separated, the defending males were displaced by attacking males, or the defending males won the contest and turned definitively the females into opposed position. Unsuccessful mates were recorded for C. sclopetarius and were associated to the inability of males in courting and defending females.

Before copulation, males rocked females violently. Then, females started to touch males on chelipeds, eyestalks, and antennules with their own antennules, indicating they were ready for copulation. Then, the pairs eased out of their shells and intertwined their ambulatories. The males put their gonopores in contact with females' gonopores for 5 to $10 \mathrm{sec}-$ onds and then they returned abruptly to their shells. After copulation, females did in and out movements in the shell without touching shell aperture (10 to 15 times during 1 to 2 minutes). This behavior was also reported in other species as Pagurus miamensis (HAzLETT 1966, synonym of P. brevidactylus) and both P. criniticornis and C. vittatus in the present study (see below). Then, males generally grasped the aperture of females' shells and returned to OGAP. More than one copulatory attempt between a pair was common in this species, which were alternated with males moving females in opposed position or OGAP.
In general, males were larger than females (mean size ratio: $42 \%$, range: 28 to 59\%). After copulation, males then alternated guarding (sensu HAzLETT 1996b) and OGAP while females generally tried to escape. Males could grasp females' chelipeds and shell lips and siphonal canals when in OGAP. Using their ambulatory legs, the males helped the females burrow into the sediment, leaving them inactive and partially to completely buried. Females also used their ambulatories to cover their shells with sediment. This post-copulatory behavior had never been described for hermit crabs (but see $C$. vittatus below) and lasted up to one hour. Females inspected after pair separation presented egg masses in early developmental stages attached to their pleopods.

There were no evidences of female molting prior to copulation and none of the successful mated females had soft exoskeletons. One individual that successfully copulated with a female was classified as intersex.

\section{Clibanarius vittatus (Bosc, 1802)}

The pre-copulatory behavior of $C$. vittatus was very similar to that described for C. sclopetarius (above) and for a North American population of $C$. vittatus (HazLetT 1996b). Males of $C$. vittatus courted females either in the opposed position or in the OGAP (Fig. 1). Cheliped tapping was evident when in opposed position with males grasping/picking the rim of females' shells or their chelipeds, ambulatories and/or eyestalks. In addition, males were also able to rotate the shells of females. Sometimes females stopped in the opposed position but with the ventral part of their bodies facing upwards. Courtship stopped due to males rejecting females or because females escaped during malemale fights. Agonistic interactions among males were very common and frequently dominated by the largest individuals. When attacked by other males, the defending males sometimes stopped guarding the females, which were able to leave.

Violent rocking movements (as recorded for C. antillensis) occurred when the pairs were in the opposed position. This behavior seemed to be a response of males to females that have been trying to escape. Such rocking movements were alternated with cheliped tapping. In some situations, males were observed holding females in the opposed position while pushing them away with cheliped extensions. During cheliped tapping, males were also seen picking/grasping females' chelipeds, ambulatories and eyestalks.

Females signaled to males they were ready for copulation by touching them in the eyestalks with their antennules. Multiple copulations between a single pair were recorded in this species and each attempt lasted up to nineteen seconds. The pairs remained in opposed position or OGAP between subsequent copulations. In one case, copulation occurred four times ( 4 to $10 \mathrm{sec}$.) within a seventeen-minute interval. In another case, a male copulated with the female and, right after loosing her, the female copulated again with the attacking male. After copulation both males and females returned rapidly to 
their shells. Females exhibited constant and fast in and out movements (4 to 5 times) in the shell aperture similarly to $C$. sclopetarius. Post-copulatory behavior was also very similar to that shown by C. sclopetarius. The pairs alternated between guarding (sensu HAzLeTT 1996b) and OGAP and the males sometimes helped the females to bury. When the pairs separated, females were generally left inactive and partially to completelly buried in the sediment. Females inspected after pairs separation had newly released egg masses attached to their pleopods.

Courtship was not reported to be associated to female molting as no exuvia were found and courted females had hardened exoskeletons. Males were always larger than females in pairs that copulated successfully (mean size ratio: $16 \%$, range: 9 to $22 \%$ ). One intersex individual was recorded successfully copulating with a female as in C. antillensis and C. sclopetarius.

\section{Pagurus criniticornis (Dana, 1852)}

The reproductive behavior in $P$. criniticornis partially followed the pagurid pattern described by HAzLETT (1966) and differed substantially from the Clibanarius species described above. Right after males had approached females they rotated females' shells until they were in the opposed position (similarly to Clibanarius species). Then the males grasped/picked the females' chelipeds and ambulatories with their chelipeds and, less frequently, with their ambulatory legs. Prior to copulation, the males held the females with their minor or major chelae in the lips of shell apertures or in the left ambulatory legs. The pairs remained frequently in an oblique position (similar to OGAP of Clibanarius, Fig. 1). Males were frequently reported dragging females about over the bottom even when no competing males were present. The characteristic pagurid jerking behavior (for description and figure see HAzLETT 1966) was not recorded in this species. When dragging stopped females grasped/picked males' chelipeds with both their chelipeds and ambulatory legs. Males also grasped females' chelipeds, ambulatories and eyestalks with their major chelae. In addition, males were also recorded rotating females' shells counter-clockwise before copulation. In one situation, a male was reported helping the female to molt by picking and pulling exuvia as previously described for C. tricolor by HAzLETT (1966). However, molting was not seen in all pairs and most courted females had hardened exoskeletons. Males of successful courting pairs were always larger than females as in the other studied species (mean size ratio: $25 \%$, range: 14 to $35 \%$ ). Agonistic interactions among males were recorded and the defending males generally used their right large chelipeds to defend the females.

Copulation occurred up to four times between a single pair and lasted from 10 to 36 seconds. Copulation time showed a tendency to be longer than in the Clibanarius species. Prior to copulation, males placed their chela inside females' shell aperture. Females signaled to males they were ready for copulation by touching male eyestalks with their antennules. Then the pairs eased out of their shells and put gonopores in con- tact. In two cases, females were using shells with a large hole in the body whorl, through which they eased out and copulated. After copulations females always retracted abruptly into their shells while males grasped their chelipeds and the margins of the aperture of their shell. Females also did in and out movements in the shell apertures for a few seconds. After that, the pairs generally remained at the shell aperture. Sometimes males put their chelipeds inside the aperture of females' shells and grasped whose chelipeds. Counter-clockwise rotations were also recorded between subsequent copulations.

In the post-copulatory behavior, males also rotated females' shells and pulled them using the minor or major chelae. Then, the pairs alternated between opposed position and OGAP, always with simultaneous grasping movements. In one case, the male was observed using his large cheliped to bury the female. Males sometimes also released females with the aperture of their shells turned upwards.

\section{GENERAL COMMENTS}

In this study, males were always larger than females in courting pairs although females could be slightly larger than males as noted for C. tricolor by Hazlett (1966). This proportionality in the sizes of males and females in courting pairs reflects the dimorphism in the size structure in hermit crab populations (TurRa \& LeITE 2000b). The size dimorphism in courting pairs and in populations reflects a selective advantage in which large males dominate the smallest ones in copulating with females (HARVEY 1990).

Intersexuality in the three studied Clibanarius species was first reported by Turra \& LeITe (2000b). Although there is little information on intersexuality in hermit crabs (see TuRRA 2004), intersex individuals certainly are able to successfully copulate females and fertilize their eggs. The frequency of intersex males copulating females was higher than the frequency of intersex in the three studied Clibanarius species in nature (see Turra \& LeITE 2000b). This may indicate that intersex males are more aggressive or that they are more efficient in locating and defending ripe females than "typical" males.

Goshima et al. (1998) showed that males of Pagurus filholi were not able to access neither ripeness nor fecundity of females that were not ready for copulation and probably courted and mated with the first ripe female they encountered. In addition these authors showed that males recognized females that were within about 5 days from spawning. In Pagurus criniticornis, individuals paired more than 24 hours before copulation. Courted females may give off reproductive pheromones that stimulate male reproductive activity, as in C. vittatus (HAzLETT 1996b). In this way, males may benefit from pairing early with females but pheromone release by females may enhance the chances of agonistic encounters with competing males. This may explain the high frequency of agonistic encounters recorded for C. sclopetarius and C. vittatus. The oblique guarding/ accessing position (OGAP) recorded in the studied species (ex- 
cept for $C$. antillensis) may represent an adaptation to deal with competitors once the defending males were still able to stimulate the females while defending them from up to five attacking males. As RiDLEy (1983) pointed out, pre-copulatory-guarding behavior is highly correlated with a short receptive interval in females. Once females are thought to be receptive after molting or spawning (HazLetT 1966) guarding seems to be a successful strategy as a pre-copulatory behavior in hermit crabs.

Unsuccessful courtships occurred frequently in both $C$. sclopetarius and C. vittatus. According to HazletT (1966, 1996b), the reasons courtships finish are: (1) males leave; (2) females leave; (3) males are unable to hold on female's shells; (4) male to male competition. In this last situation, defending males may loose females to attacking males or females may leave because they were not guarded adequately. Despite the fact that male-male contests were frequent, the winners sometimes left females without copulating them. It probably occurred because the former males paired with females whose physiological status was not close to ripeness.

The comparison between studies on the hermit crab reproductive behavior revealed that the general behavioral pattern is very similar among populations. However, rotation in C. sclopetarius and C. vittatus was not as conspicuous as described in the typical Diogenid pattern (HazletT 1966, 1996a). This behavior was frequently observed only in C. antillensis. On the other hand, previous descriptions for C. sclopetarius and C. vittatus did not record the evident pre and post-copulatory OGAP shown in the present study. Female in and out movements in shell aperture after copulation were also not recorded in previous descriptions for the studied species (HAZLETT 1966, 1996a). In addition, the post-copulatory behavior of $C$. sclopetarius, $C$. vittatus and even $P$. criniticornis showed that females were frequently left inactive and/or partially to totally buried after being released by the males.

\section{ACKNOWLEDGEMENTS}

I would like to thank Fundação de Amparo à Pesquisa do Estado de São Paulo (FAPESP, Proc. N 98/00483-0) and CAPES for scholarship grants and to FAEP for partially funding this research. Centro de Biologia Marinha of Universidade de São Paulo (CEBIMar-USP) make available facilities to conduct the experiments presented in this contribution. Fosca P. P. Leite advised my PhD thesis from which this publication is derived. Thanks to Karen M. S. Brito, Roberto M. Shimizu, Ana Maria S. P. Vanin, Cláudia A. Magalhães, Thomas M. Levinsohn, and Fosca P. P. Leite for valuable comments on early versions of the manuscript.

\section{REFERENCES}

Asakura, A. 1987. Population ecology of the sand-dwelling hermit crab Diogenes nitidimanus Terao: 3. Mating system. Bulletin of Marine Science, Miami, 41: 282-288.
DE WILde, P.A.W.J. 1973. On the ecology of Coenobita clypeatus in Curaçao with reference to reproduction, water economy and osmoregulation in terrestrial hermit crabs. Studies on fauna of Curaçao and other Caribbean Islands, Amsterdam, 144: 1-138.

Elwood, R.W. \& S.J. NeIl 1992. Assessments and decisions - a study of information gathering by hermit crabs. London, Chapman and Hall, 192p.

Forest, J. \& M. Saint Laurent. 1968. Campagne de la "Calypso" au large de côtes Atlântiques de l'Amerique du Sud (19611962). 6. Crustacés Décapodes: Pagurides. Annales de L'Institut Oceanographique, Monaco, 45: 47-169.

Goshima, S.; T. Kawashima \& S. Wada. 1998. Mate choice by males of the hermit crab Pagurus filholi: Do males assess ripeness and/or fecundity of females? Ecological Research, London, 13: $151-161$.

Harvey, A.W. 1990. Sexual differences in contemporary selection acting on size in the hermit crab Clibanarius digueti. American Naturalist, Chicago, 136: 292-304.

Hazlett, B.A. 1966. Social behavior of the Paguridae and Diogenidae of Curaçao. Studies on fauna of Curaçao and other Caribbean Islands, Amsterdam, 23: 1-143.

Hazlett, B.A. 1968. The sexual behavior of some European hermit crabs. Pubblicazione della Stazione Zoologica di Napoli, Nápoles, 36: 238-252.

Hazlett, B.A. 1972. Shell fighting and sexual behavior in the hermit crab genera Paguristes and Calcinus with comments on Pagurus. Bulletin of Marine Science, Miami, 22: 806-823.

Hazlett, B.A. 1975. Ethological analysis of reproductive behavior in marine Crustacea. Pubblicazione della Stazione Zoologica di Napoli, Nápoles, 39: 677-695.

Hazlett, B.A. 1986. Sexual behavior of the hermit crab Pagurus traversi (Filhol) (Decapoda, Paguridea). Crustaceana, Leiden, 51: 107-108.

Hazlett, B.A. 1989. Mating success of male hermit crabs in shell generalist and shell specialist species. Behavioral Ecology and Sociobiology, Heidelberg, 25: 119-128.

HazLETt, B.A. 1996a. Precopulatory behavior of the hermit crabs Diogenes avarus and Clibanarius virescens. Australian Journal of Zoology, Collingwood, 44: 487-492.

HazLetT, B.A. 1996b. Reproductive behavior of the hermit crab Clibanarius vittatus (Bosc, 1802). Bulletin of Marine Science, Miami, 58: 668-674.

HAzLETT, B.A. \& L.C. BARON. 1989. Influence of shells on matingbehavior in the hermit crab Calcinus tibicen. Behavioral Ecology and Sociobiology, Heidelberg, 24: 369-376.

Helfman, G.S. 1977. Copulatory behavior of the coconut or robber crab Birgus latro (L.) (Decapoda, Anomura, Paguridea, Coenobitidae). Crustaceana, Leiden, 33: 198-202.

Ridley, M. 1983. The explanation of organic diversity: the comparative methods and adaptations for mating. Oxford, Claredon Press, 272p.

TURRA, A. 2004. Intersexuality in hermit crabs: reproductive role 
and fate of gonopores in intersex individuals. Journal of the Marine Biological Association of the United Kingdom, Cambridge, 84: 757-759.

TurRA, A. \& F.P.P Leite. 2000a. Clustering behavior of hermit crabs (Decapoda, Anomura) in an intertidal rocky shore at São Sebastião Channel, southeastern Brazil. Brazilian Journal of Biology, São Carlos, 60: 39-44.

Turra, A. \& F.P.P LeITe. 2000b. Population biology and growth of three sympatric species of intertidal hermit crabs in southeastern Brazil. Journal of the Marine Biological Association of the United Kingdom, Cambridge, 80: 1061-1069.
Turra, A. \& M.R. Denadai. 2002. Substrate use and selection in sympatric intertidal hermit crab species. Brazilian Journal of Biology, São Carlos, 62: 107-112.

Turra, A. \& M.R. Denadai. 2003. Daily activity of four tropical intertidal hermit crabs from southeastern Brazil. Brazilian Journal of Biology, São Carlos, 63: 537-544.

Turra, A.; G.B. Jacobucci; F.M.P. Araújo \& F.P.P. Leite. 2000. Spatial distribution of four sympatric species of hermit crab (Decapoda, Anomura), p. 261-273. In: J.C.V. Klein \& F. Schram (Eds). The biodiversity crisis and crustacea. Rotterdam, A.A. Balkema, 848p.

Received in 05.VIII.2004; accepted in 01.V.2005. 